\title{
STUDI PENGELOLAAN SAMPAH DI PASAR SAYUR DAN BUAH KECAMATAN PEMALANG KABUPATEN PEMALANG TAHUN 2016
}

\author{
Muhammad Fadli Rachman ${ }^{1)}$, Retno Kusumaningrum²), Khomsatun ${ }^{3)}$ \\ Jurusan Kesehatan Lingkungan, Politeknik Kesehatan Kemenkes Semarang, \\ Jl. Raya Baturaden KM 12 Purwokerto, Indonesia
}

\begin{abstract}
Abstrak
Pasar merupakan tempat untuk melakukan aktifitas transaksi antara penjual dan pembeli. Pasar selalu menghasilkan sampah dengan jumlah banyak. Sampah yang tidak dikelola dengan baik akan menimbulkan dampak negatif bagi manusia , pencemaran lingkungan hingga menimbulkan penularan penyakit. Tujuan penelitian ini adalah mendeskripsikan tentang penimbulan sampah, pewadahan sampah, pengumpulan sampah, pengangkutan sampah, pengolahan sampah dan pembuangan akhir sampah.

Penelitian ini dilakukan dengan metode deskriptif yaitu mendiskripsikan tentang pengelolaan sampah di Pasar Sayur dan Buah Kecamatan Pemalang, meliputi penimbulan sampah, pewadahan sampah, pengumpulan sampah, pengangkutan sampah, pengolahan sampah dan pembuangan akhir sampah.

Hasil penelitian menunjukan bahwa pengelolaan sampah di Pasar Sayur dan Buah Kecamatan Pemalang dengan jumlah penimbulan sampah rata-rata yaitu : 17,67 $\mathrm{m}^{3}$, yang terdiri dari sampah organik $15,57 \mathrm{~m}^{3}$ dan sampah anorganik 2,10 $\mathrm{m}^{3}$. Permasalahan yang ditemukan di Pasar Sayur dan Buah Kecamatan Pemalang Kabupaten Pemalang antara lain jumlah sarana pewadahan sampah tidak mencukupi, kontruksi tempat sampah tidak berpenutup, berkarat dan pegangan tangan sudah hilang.

Kesimpulan dalam penelitian ini adalah sistem pengelolaan sampah di Pasar Sayur dan Buah Kecamatan Pemalang belum memenuhi syarat, yaitu seperti belum adanya pengawasan dari pengelola pasar, sarana tempat sampah yang belum memenuhi syarat dan jumlah sarana tempat sampah tidak sesuai dengan jumlah kios dan los pasar serta Alat Pelindung Diri (APD) yang digunakan petugas kebersihan belum lengkap. Saran bagi pihak pengelola pasar yaitu lebih meningkatkan pengawasan, tersedianya sarana pewadahan sampah yang memenuhi syarat dan menyediakan APD yang lengkap bagi petugas kebersihan.
\end{abstract}

Kata Kunci : Pengelolaan Sampah Pasar

\begin{abstract}
Market is a place to perform activities of transactions between seller and buyer. The market always produces much garbage. Garbage's amount that is not managed properly will have negative impacts for humans, environmental pollution to cause transmission of the disease. Purpose of this study is to describe the waste management in the fruit and vegetable market pemalang districts, including the onset of trash, lug garbage, waste collection, waste transportation, waste processing and disposal of garbage.

This research is done with descriptive method that describes the waste management in the Fruit and Vegetable Market District of Pemalang, including the onset of trash, lug garbage, waste collection, waste transportation, waste processing and disposal of garbage.

Research shows that waste management in the Fruit and Vegetable Market District of Pemalang by the number of garbage onset average namely: $17.63 \mathrm{~m} 3$, which is made up of organic waste and inorganic $15.57 \mathrm{~m} 3$ $2.10 \mathrm{~m} 3$. Problems found in the Fruit and Vegetable Market Districts Pemalang including the amount of garbage lug means are insufficient, the construction is not a covered trash, rusted and handrails are gone.

Conclusions in this research is the waste management system in the Fruit and Vegetable Market Districts Pemalang yet qualified, that such lack of oversight and market managers, tool bins are not eligible and the number of facilities the trash does not correspond to the number of market stalls, as well as tools protective (PPE) used janitor is not yet complete. Suggestions for the market management which further improve oversight, provided it means lug garbage that is qualified and provide a complete PPE for the janitors.
\end{abstract}

Keywords : waste management

\footnotetext{
${ }^{1)}$ E-mail: Fadlim519@gmail.com

${ }^{2)}$ E-mail: retnokusumaningrum69@yahoo.com

${ }^{3)}$ E-mail: daplunrokhim@gmail.com
} 


\section{PENDAHULUAN}

Semakin berkembangnya berbagai aktivitas yang dilakukan oleh manusia untuk memenuhi kebutuhan dan kesejahteraan hidupnya dengan memproduksi makanan, minuman dan barang lain dari sumber daya alam. Selain menghasilkan barangbarang yang akan dikomsumsi, aktivitas tersebut juga menghasilkan bahan buangan yang sudah tidak dibutuhkan oleh manusia, yaitu sampah. Sampah yang dihasilkan tidak hanya berupa bahan organik, tetapi juga sampah anorganik seperti kaleng, plastik dan bahan-bahan lain yang tidak mudah busuk. Upaya dalam bentuk penanganan terhadap sampah dapat dilakukan dengan pengelolaan sampah mulai dari penimbulan sampah sampai dengan pembuangan akhir sampah. (Budiman chandra, 2007, h. 111).

Sekilas sampah selalu menjadi momok menakutkan akibat dampak negatif yang ditimbulkannya. Selain menurunkan higenis dan kualitas lingkungan, keberadaan sampah senantiasa menimbulkan problematika sosial yang cukup pelik diberbagai pihak padahal sampah tidak selamanya harus dibuang. Dengan sedikit kreatifitas dan kerja keras, sampah tidak layak pakai dapat disulap menjadi barang kaya manfaat. Beraneka produk olahan sampah bisa digunakan untuk menunjang kehidupan manusia sekaligus memperbaiki kualitas alam. Begitu banyak sampah yang dapat di daur ulang dan dikomersilkan dalam lingkaran usaha baik modern maupun tradisional. Beragam jenis sampah, terutama sampah organik dapat dengan mudah dan sederhana di aplikasikan menjadi bahan olahan seperti kompos, pupuk cair, biogas dan briket mempunyai pangsa pasar yang cukup menjanjikan dimasa datang. (Tim penulis PS, h.3)

Sampah tidak dapat dipisahkan dari kehidupan manusia, sebab pada dasarnya sampah merupakan produk yang sebetulnya tidak diharapkan adanya. Timbulnya sampah yang berakumulasi menyebabkan manusia berupaya untuk mengatasinya, sebab telah diyakini adanya pengaruh-pengaruh negatif yang ditimbulkan oleh karenanya. Usaha ini telah lama dijalankan oleh badan-badan pemerintah maupun swasta. Masalah sampah ini tidak pernah menjadi lebih kecil. Tahun demi tahun biaya yang harus dikeluarkan untuk pengelolaan sampah selalu meningkat. Oleh karena itu pengelolaan secara ekonimis dan efisien sangat didambakan. Peraturan disusun dan disyahkan sebagai landasan pengelola sampah dalam menangani masalah tersebut. (Didik Sarujdi, 1982, h.1) .

Pengelolaan sampah yang kurang baik sangat memberikan pengaruh negatif bagi kesehatan manusia , lingkungan, maupun bagi kesehatan sosial ekonomi dan budaya masyarakat yaitu gangguan estetika (pemandangan dan bau-bau yang tidak sedap), menjadi tempat berkembang biaknya vektor yang dapat menjadi penularan penyakit demam berdarah dan secara langsung dapat mencemari lingkungan. Tempat umum sebagai bagian dari lingkungan fisik, yang dapat berpotensi menimbulkan penularan penyakit dan terjadinya kecelakaan. Tempat-tempat umum yang dimaksud dapat berupa pasar, terminal bus, stasiun kereta api dan-lain-lain. Pasar merupakan salah satu tempat-tempat umum sebagai tempat orang-orang berkumpul untuk melakukan kegiatan jual beli barang-barang kebutuhan sehari-hari, sangatlah perlu adanya pengawasan terhadap sanitasinya. Pengawasan yang dilakukan untuk mencegah terjadinya penularan penyakit, baik antara pedagang dan pembeli, pedagang dengan pedagang ataupun antara pembeli dengan pembeli. Penularan penyakit tersebut dapat melalui kontak langsung melalui vektor penyakit dalam pasar tidak terlepas dari adanya kegiatan jual beli yang selalu menghasilkan sampah dan bau-bauan yang khas. (Budiman Chandra, 2007, h.122).

Pasar Sayur dan Buah Kecamatan Pemalang Kabupaten Pemalang hanya memiliki 6 petugas kebersihan yang harus menangani timbulan sampah dari 140 los, 72 kios dan 63 lapak gudang. Rata-rata sampah yang dihasilkan di Pasar Sayur dan Buah Kecamatan Pemalang Kabupaten Pemalang. Ratarata sampah perhari yang dihasilkan di Pasar Sayur dan Buah Kecamatan Pemalang Kabupaten Pemalang sebanyak 6 ton per hari.Sistem pengangkutan sampah dari pasar menuju TPAmenggunakan truk sampahsebanyak 2 kali dalam sehari, pagi hari dan menjelang sore hari. Dengan sedikitnya jumlah petugas kebersihan, banyaknya pengunjung pasar dan sistem operasional pasar selama 24 jam, maka akan berpengaruh pada timbulan sampah.

Sehubungan dengan dampak sampah pasar tersebut di atas peneliti ingin mengadakan penelitian dengan judul : “Tinjauan Pengelolaan Sampah Di Pasar Sayur dan Buah Kecamatan Pemalang Kabupaten Pemalang Tahun 2016”.

Tujuan penelitian ini adalah untuk Mengetahui tentang pengelolaan sampah di Pasar Sayur dan Buah Kecamatan Pemalang Kabupaten Pemalang Tahun 2016.

Manfaat penelitian bagi pemerintah adalah Menambah masukan dalam pengelolaan sampah di Pasar Sayur dan Buah, bagi pengelola pasar adalah diperolehnya gambaran pengelolaan sampah sehingga dapat menjadi bahan masukan tentang pengelolaan sampah di Pasar Sayur dan Buah, bagi almamater adalah menambah reverensi kepustakaan kampus 7 Politeknik Kesehatan Kemenkes Semarang Jurusan Kesehatan Lingkungan dan materi khususnya dalam proses pengelolaan sampah bersumber dari institusi pasar, bagi peneliti adalah merupakan kesempatan untuk mendapatkan pengalaman dan memperluwas wawasan di bidang pengelolaan sampah khusunya yang bersumber di pasar.

\section{METODE PENELITIAN}

Penelitian yang dilakukan adalah penelitian deskriptif. Penelitian deskriptif dimaksudkan untuk 
mendeskripsikan secara sistematis dan akurat suatu situasi atau area populasi tertentu yang bersifat aktual tentang Pengelolaan Pasar Sayur dan Buah Kecamatan Pemalang Kabupaten Pemalang.

Lokasi penelitian ini dilaksanakan di Pasar sayur dan Buah kecamatan Pemalang Kabupaten Pemalang. Penelitian ini dilaksanakan pada bulan Juni 2016

Subyek penelitian ini adalah pengelolaan sampah yang meliputi penimbulan, pewadahan, pengumpulan, pengolahan, pengangkutan, pembuangan akhir di pasar sayur dan buah Kecamatan Pemalang Kabupaten Pemalang.

\section{HASIL DAN PEMBAHASAN}

A. Gambaran Umum Pasar Sayur dan Buah Pasar Sayur dan Buah Kabupaten Pemalang berdiri pada tanggal 29 Maret 2009, terletak di Jalan Slamet Riyadi nomer 1 Kelurahan Mulyoharjo Kecamatan Pemalang Kabupaten Pemalang. Luas wilayah Pasar Sayur dan Buah adalah 1,4 hektar yang terbagi menjadi 72 kios, dan 140 los, dengan jumlah pedagang tetap 212 orang, jumlah pedagang tidak menetap 116 orang. Aktivitas pasar berlangsung mulai pukul 05.00- WIB sampai pukul 16.00 WIB.

Batas administratif Pasar sayur dan Buah Kecamatan Pemalang Kabupaten Pemalang adalah sebagai berikut :

a. Sebelah timur: Lahan pertanian penduduk

b. Sebelah selatan : Desa Mulyoharjo

c. Sebelah barat : Pasar Induk Kabupaten Pemalang

d. Sebelah utara : Lahan pertanian penduduk Pedagang yang ada di Pasar Sayur dan Buah menjual berbagaii macam barang kebutuhan pokok rumah tangga. Barang dagangan yang banyak diperjualbelikan di Pasar Sayur dan Buah Kecamatan Pemalang Kabupaten Pemalang adalah sayur-sayuran, buah-buahan, makanan dan barang-barang kebutuhan dagangan lainnya. Adapun jenis barang dagang di Pasar Sayur dan Buah antara lain :
a. Sayur-sayuran
b. Buah-buahan
c. Bumbu dapur
d. Pedagang sandal
e. Peralatan rumah tangga

Dari jenis barang dagang diatas yang menimbulkan sampah paling banyak berasal dari pedagang sayuran dan pedagang buah.

B. Upaya Mangemen Pengelolaan Sampah Pasar sayur dan Buah

1. Perencanaan

a. Karyawan : karyawan yang mengelola pasar sayur dan buah secara keseluruhan sebanyak 14 orang dengan status pegawai tetap dan kontrak. Diantara 14 pegawai tersebut 2 orang diantaranya pegawai tetap, 9 orang pegawai kontrak dan 3 orang tenaga harian lepas.

b. Bahan : bahan yang digunakan di pasar sayur dan buah adalah struktur organisasi pengelolaan sampah pasar.

c. Peralatan : peralatan yang ada meliputi sapu lidi, sekop, cangkul, garuk, cangkul, gerobak sampah dan arm roll.

d. Metode : metode yang digunakan dalam sebuah perencanaan pengelolaan sampah pasar sayur dan buah dari penimbulan sampai dengan pembuangan akhir.

e. Biaya : biaya retribusi yang dikenakan pedagang kios Rp. 4.500, pedagang los Rp. 1.400. dan pedagang plataran Rp. 1200.

2. Organisasi pasar sayur dan buah

Organisasi pasar sayur dan buah dipimpin oleh Kepala Unit Pengelolaan Pasar yang membawahi Staf Keuangan 2 orang, Staf Administrasi Umum (TU) 2 orang, Staf Retribusi 3 orang, staf Keamanan 7 orang dan Staf Kebersihan 6 orang. Pasar sayur dan buah tidak mempunyai susunan struktur organisasi khusus pengelolaan sampah. Petugas pelaksana pengelola sampah di Pasar Sayur dan Buah Pemalang dalam melakukan kegiatan mengelola sampah hanya menggunakan Alat Pelindung Diri (APD) berupa helm/topi, pakaian lengan panjang dan sepatu boot. Tingkat pendidikan petugas kebersihan di Pasar Sayur dan Buah Pemalangtergolong rendah terdiri dari lulusan SD sebanyak 1 orang, SMP 3 orang, SMA 2 orang

Organisasi pengelolaan sampah pasar sayur dan buah dikondisikan oleh Kepala Pengelola Pasar yang bertugas untuk mengawasi dalam pelaksanaannya seperti pelaksanaan urusan kebersihan, keamanan dan ketertiban oleh petugas pasar yang sudah diperintah oleh Kepala Pengelola Pasar.

Menurut Kepmenkes RI Nomor 1204 Tahun 2004 menjelaskan tata laksana kepada petugas yang menangani sampah harus menggunakan alat pelindung diri (APD) diri berupa :

\section{a. Topi / Helm}

Berfungsi sebagai pelindung kepala dari beda yang bisa mengenai kepala secara langsung.

b. Masker

Berfungsi sebagai penyaring udara yang dihirup saat bekerja ditempat dengan kualitas udara yang buruk.

c. Pelindung mata

Berfungsi sebagai pelindung mata saar bekerja

d. Pakaian panjang 
Berfungsi untuk melindungi badan sebagian atau seluruh seluruh bagian badan dari bahaya saat melakukan pekerjaan.

e. Apron untuk indrustri

Berfungsi sebagai pelindung badan dari bahaya temperatur panas atau dingin yang ekstrim, pajanan api, benda panas dan percikan bahan kimia.

f. Pelindung kaki/ Sepatu boot

Berfungsi sebagai alat pengaman saat bekerja ditempat yang becek atau berlumpur.

g. Sarung tangan khusus

Berfungsi sebagai alat untuk melindungi tangan dari cedera saat bekerja ditempat atau situasi yang dapat menyebabkan cedera tangan.

C. Gambaran Khusus Pengelolaan Sampah Pasar Sayur dan Buah

1. Deskripsi Penimbulan Sampah

Sampah dihasilkan dari para pedagang pasar, terutama pedagang bahan makanan : penjual sayur-sayuran, buah-buahan, bumbu dapur dan lain-lain. Pedagang yang menjual bahan perlengkapan rumah tangga, pedagang sandal dan lain-lain, tidak banyak menghasilkan sampah. Selain dari pedagang, sampah juga berasal dari pengunjung yang datang ke Pasar Sayur dan Buah Kecamatan Pemalang Kabupaten Pemalang.

Berdasarkan hasil pengukuran sampah yang dilakukan dengan menggunakan gerobak sampah yang telah diukur terlebih dahulu, maka dapat diketahui bahwa jumlah atau volume sampah yang dihasilkan di Pasar Sayur dan Buah Kecamatan Pemalang Kabupaten Pemalang selengkapnya :

\begin{tabular}{llcccc}
\hline $\begin{array}{c}\text { N } \\
\text { o }\end{array}$ & Hari & \multicolumn{2}{c}{$\begin{array}{c}\text { Volume Sampah } \\
\left(\mathrm{m}^{3}\right)\end{array}$} & \multicolumn{2}{c}{ Prosentase \% } \\
\cline { 3 - 6 } & & $\begin{array}{c}\text { Organ } \\
\text { ik }\end{array}$ & $\begin{array}{c}\text { Anorgan } \\
\text { ik }\end{array}$ & $\begin{array}{c}\text { Organ } \\
\text { ik }\end{array}$ & $\begin{array}{c}\text { Anorgan } \\
\text { ik }\end{array}$ \\
\hline 1 & Ming & 18,09 & 0,81 & 29.03 & 9.60 \\
& gu & & & & \\
2 & Senin & 16,08 & 1,2 & 25.80 & 14.2 \\
3 & Selasa & 15,41 & 1,87 & 24.20 & 22.1 \\
4 & Rabu & 12,73 & 4,55 & 20.40 & 53.9 \\
\hline & Jumla & 62,31 & 8,43 & 100 & 100 \\
& h & & & & \\
\hline & Rata- & 15,57 & 2,10 & 25 & 25 \\
& rata & & & & \\
\hline
\end{tabular}

Berdasarkan hasil pengukuran, diketahui bahwa dalam tahap penimbulan sampah, volume sampah yang dihasilkan di Pasar Sayur dan Buah 17,67 $\mathrm{m}^{3}$ /hari, yang terdiri dari sampah organik 15,57 $\mathrm{m}^{3}$ dan sampah anorganik $2,10 \mathrm{~m}^{3}$. Permasalahan pada tahap ini belum dilakukan pemisahan antara sampah organik dan anorganik, dikarenakan sarana pewadahan sementara dengan jumlah yang tidak cukup dan rusak, sehingga volume sampah tidak melebihi kapasitas pewadahan sampah.

\section{Deskripsi Pewadahan Sampah}

Para pedagang Pasar Sayur dan Buah Kecamatan Pemalang Kabupaten Pemalang sebagian besar tidak memiliki kontainer sampah namun pihak pasar menyediakan tempat sampah di kios-kios dan los-los pasar dengan jenis pewadahan berupa drum, dan juga pihak pasar menyediakan sebuah gerobak sampah guna untuk berjaga-jaga jika sampah melebihi volume tempat yang sudah disediakan.

Di Pasar Sayur dan Buah terdapat 150 unit tempat pewadahan sampah berupa drum dan keranjang sampah yang diletakan disekitar kios-kios pasar, los-los pasar dan sekitar lingkungan pasar, untuk tempat pewadahan sampah berupa drum disediakan oleh Balai Lingkungan Hidup Pemalang berupa sumbangan sebanyak 200 unit, namun kondisi tempat pewadahan sampah berupa drum tidak dirawat dan banyak yang rusak.Sedangkan keranjang sampah berasal dari hasil retribusi pedagang.

Tempat pewadahan sampah di Pasar Sayur dan Buah Pemalang baik berupa drum maupun keranjang sampah kondisinya sangat memprihatinkan, hal ini dikarenakan tempat pewadahan sampah kurang dari jumlah yang seharusnya, dan tempat pewadahan sampah yang disediakan Pasar Sayur dan Buah semuanya belum memenuhi syarat diantaranya berkarat, pegangan tangan sudah hilang dan tidak ditutup. Menurut pedagang tempat pewadahan sampah tidak ditutup karena sampah melebihi kapasitas tempat pewadahan sampah.

Menurut Depkes RI (1987, h. 34) syarat-syarat tempat penampungan sampah diantaranya adalah sebagai berikut :

1). Tidak mudah berkarat

2). Terbuat dari bahan yang kuat, ringan dan kedap air

3). Mempunyai tutup

4). Mudah diisi dan dikosongkan serta mudah dibersihkan

5). Mempunya pegangan tangan / handle dikedua belah sisinya

6). Alasnya tidak berlubang.

3. Deskripsi Pengumpulan Sampah

Proses pengumpulan sampah di Pasar Sayur dan Buah Kecamatan Pemalang Kabupaten Pemalang dilakukan oleh petugas kebersihan 
yang ditunjuk oleh kepala pengelola pasar untuk memelihara kebersihan pasar. Petugas kebersihan pasar hanya berjumlah 6 orang dengan status pegawai tidak tetap. Sampah yang dihasilkan dari setiap kegiatan pasar dilokasi kios-kios pasar dan los-los pasar dibersihkan dan dikumpulkan dalam sebuah gerobak sampah, untuk selanjutnya petugas kebersihan membuang sampah tersebut ke arm roll yang berada di TPS (tempat penampungan sementara).

Dalam mengumpulkan sampah Petugas hanya menggunakan topi, pakaian lengan panjang dan sepatu boot.Pada saat melakukan tugasnya petugas pelaksana kebersihan diwajibkan menggunakan APD lengkap seperti : helm/topi, masker, lengan panjang, sarung tangan dan sepatu boot guna menghindari penularan penyakit yang terjadi secara kontak langsung antara tangan dengan sampah dan menghirup bau yang tak sedap.

\section{Deskripsi Pengangkutan Sampah}

Pengangkutan sampah Pasar Sayur dan

Buah Kecamatan Pemalang Kabupaten Pemalang berawal dari proses pengumpulan sampah di kios-kios pasar dan los-los pasar, oleh petugas kebersihan pasar kemudian diangkut ke TPS. Di TPS terdapat proses pemisahan sampah organik dan sampah anorganik oleh pihak ketiga yaitu pengrajin kerajinan tangan. Sampah organik dimanfaatkan menjadi pupuk kompos dan sampah anorganik di daur ulang menjadi kerajinan berupa keranjang dan botol bekas plastik yang dimodifikasi menjadi bunga. Sampah yang tidak diolah diangkut ke TPA yang berada di Desa Pesalakan Kecamatan Pemalang menggunakan truk pengangkut sampah.

Alat angkut truk sampah sebanyak 1 unit. Truk pengangkut sampahini masih dalam kondisi baik, namun tidak dilengkapi jaringjaring sehingga sampah yang terangkut bisa jatuh dan tercecer sepanjang jalan apabila melebihi kapasitas volume arm roll. Sedangkan amrol tidak berpenutup dan kapasitas volume amrol 8,64 $\mathrm{m}^{2}$. Namun ada beberapa truk sampah dan amrol yang kurang mendapatkan perawatan, yaitu jarang dicuci setelah digunakan sehingga menimbulkan bau dan mengundang lalat.

Waktu pengangkutan sampah dari kioskios pasar, los-los pasar ke amrol dilakukan pada pagi hari pukul 07.00-08.00 WIB dan sore hari pukul 16.00 WIB sampai selesai.

\section{Deskripsi Pemanfaatan Sampah}

Menurut petugas pengolahan sampah di Pasar Sayur dan Buah Kecamatan Pemalang Kabupaten Pemalang, bahwa sampah organik dimanfaatkan kembali dengan cara membuat pupuk kompos yang dijual belikan ke konsumen, sedangkan sampah anorganik dimanfaatkan dengan mendaur ulang menjadi kerajinan berupa keranjang, dan botol bekas plastik yang dimodifikasi menjadi bunga, tetapi pemanfaatan sampah di Pasar Sayur dan Buah Kecamatan Pemalang Kabupaten Pemalang dilakukan oleh pihak ketiga yaitu pengrajin kerajinan tangan.

\section{Deskripsi Pembuangan Akhir}

Pembuangan akhir sampah dari arm roll dilakukan setiap 2-3 kali dalam sehari setelah sampah di amrol sudah penuh. Proses pembuangan akhir dilakukan oleh Dinas Pekerja Umum (DPU) Kabupaten Pemalang. Sampah diangkut kemudian dibuang ke tempat pembuagan akhir (TPA) yang berada di Desa Pesalakan Kecamatan Pemalang Kabupaten Pemalang. Metode yang digunakan yaitu open dumping yang ditumpuk begitu saja kemudian dibakar. Hasil buangan sampah dari berbagai tempat akan menimbulkan dampak negatif. Dampak negatif di TPA Desa Pesalakan Kecamatan Pemalang ini sudah terlihat seperti bau tidak enak yang sangat menyengat, dan keberadaan populasi lalat yang bisa menjadi sumber penyakit.

\section{KESIMPULAN DAN SARAN}

A. Kesimpulan

1. Sumber sampah di Pasar Sayur dan Buah yang berasal dari pedagang sayur dan pedagang buah di kios dan los pasar.

2. Tempat pewadahan sampah di Pasar Sayur dan Buah Kecamatan Pemalang Kabupaten Pemalang jenis pewadahan keranjang sampah dan drum sampah, dengan kondisi diantaranya berkarat, berlubang, pegangan tangan sudah hilang dan tidak berpenutup.

3. Pengumpulan sampah Pasar Sayur dan Buah Pemalang dilakukan oleh petugas kebersihan den,gan jumlah 6 orang. Pengumpulan sampah dilakukan pada pagi hari pukul 07.00-08.00 WIB dan sore pukul 16.00 WIB- selesai. Yang bertanggung jawab pada proses pengumpulan sampah adalah Perusda Pemalang

4. Pengangkutan sampah dilakukan oleh Dinas Pekerja Umum (DPU) khususnya di Unit Kebersihan dan Pertamanan Kabupaten Pemalang.

5. Pemanfaatan sampah di Pasar Sayur dan Buah Pemalang sudah menerapkan pengolahan sampah organik diolah menjadi 
kompos dan sampah anorganik didaur ulang menjadi kerajinan tangan oleh pihak ketiga yaitu pengrajin kerajinan tangan.

6. Pembuangan akhir sampah ke TPA (tempat pembuangan akhir) menggunakan metodeopen dumping yang ditumpuk kemudian di bakar.

B. Saran

1. Sebaiknya pihak Pasar Sayur dan Buah Kecamatan Pemalang Kabupaten Pemalang dapat menyediakan sarana tempat sampah dengan jumlah yang sesuai kios-kios pasar, los-los pasar dan tempat sampah yang memenuhi syarat seperti kontruksi kuat, mudah dibersihkan, mudah dikosongkan, mudah diangkut, tidak mudah berkarat, dan berpenutup. Diharapkan dengan adanya sarana tempat sampah yang sesuai dengan jumlah kios pasar dan los pasar dan tempat sampah yang memenuhi syarat, maka kebersihan dapat terjamin dan mengurangi resiko penularan penyakit.

2. Menghimbau kepada pedagang untuk menjaga kebersihan sekitarnya dari sampah serta kesadaran untuk merawat fasilitasfasilitas kebersihan yang telah disediakan oleh pihak pasar.

3. Petugas kebersihan hendaknya menggunakan alat pelindung diri (APD) lengkap seperti : helm/topi, pakaian kerja, sarung tangan, masker, lengan panjang, sepatu boot. Untuk keamanan dan keselamatan dalam bekerja dan menghindari dari resiko penularan penyakit.

4. Pengelola pasar Sayur dan Buah Kecamatan Pemalang Kabupaten Pemalang hendaknya memasang papan himbauan supaya menjaga kebersihan.

\section{DAFTAR PUSTAKA}

Budiman, Chandra, 2007. Pengantar Kesehatan lingkungan. Jakarta : Penerbit Buku Kedokteran EGC.

Budiman, Chandra, 2009. Ilmu Kedokteran Pencegahan dan Komunitas. Buku Kedokteran. EGC. Jakarta.

Damanhuri, E. 2004. Diklat Kuliah Pengelolaan Sampah TL-3150, Teknik Lingkungan ITB, Edisi Semester I 2004/2005, Bandung

Didik, Sarudji, 1982. Pengolahan Sampah, Instalasi Penerbitan APKTS, Surabaya.
Didik, Sarudji, 2010. Kesehatan Lingkungan, Bandung : CV. KARYA PUTRA DARWATI.

Dirjen PPM dan PLP, 2008. Pedoman Penyelenggaraan Pasar Sehat, Jakarta.

Departemen Pekerjaan Umum. 2004. SNI 197029-2004 Spesifikasi Komposter Rumah Tangga Individual dan Komunal. Yayasan LPMB Bandung.

George R. Terry Ph. D. 1988, Principles Of Manajemen, Bandung: P.T. Alumni.

Indonesia, Departemen Kesehatan RI, 1987. Pedoman Bidang Studi Sampah, Jakarta : Departemen Kesehatan RI.

Kiva Microfinance, 2007. Tempat-SampahOtomatis www.g2glive.com. Diakses pada tanggal 11 Desember 2015.

Kuncoro, Sejati, 2009. Pengolahan Sampah Terpadu Dengan Sistem Note, Sub Point, Centre Poin. Yogyakarta : Kanisius. (anggota IKAPI).

Keputusan Menteri Perindustrian perdagangan Republik Indonesia Nomer 23/MPP/KEP/1/1998 Tentang Lembaga-Lembaga Usaha Perdagangan

Masri Singarimbun dan Sofian Efendi, 1989. Metode Penelitian Survay, Jakarta : LP3ES.

Notoatmojo, S. 2007. Kesehatan Masyrakat Ilmu dan Seni, Jakarta : Rineka Cipta.

Suharsimi Arikunto, 1985, Prosedur Penelitian, Jakarta : Bina Aksara

Soedarso , 1985. Studi Pembuangan Sampah, Sekolah Pembantu Penilik Hygiene, Surabaya

Tim Penulis PS, 2008. Penanganan dan Pengolahan Sampah, Jakarta : Penebar Surabaya.

Undang-Undang Republik Indonesia No. 36 Tahun 2009 Tentang Kesehatan. Jakarta : Departemen RI

Undang-Undang RI No 18 Tahun 2008 Tentang Pengelolaan sampah. 